\title{
44. SHORT-CHAIN ORGANIC ACIDS IN INTERSTITIAL WATERS FROM THE TONGA ARC-TRENCH SYSTEM, LEG $135^{\perp}$
}

\author{
Janet A. Haggerty ${ }^{2}$ and J. Berton Fisher ${ }^{3}$
}

\begin{abstract}
For the first time, short-chain organic acids are described in interstitial waters from sediments and lithified materials in a backarc setting. Organic acids in interstitial waters from the Tonga forearc region were also analyzed and compared with previous organic acid analyses from the Mariana and Bonin forearc interstitial waters.

In the Tonga backarc setting, propionate typically dominates the organic acid assemblage, and organic acids are a consistent feature of these interstitial waters. The persistent presence of ammonia and the dominance of propionate over formate in the backarc interstitial waters suggest that the organic acids in this setting have their origin in reductive deamination of amino acids derived from sedimentary proteinaceous material.

The organic acid assemblage revealed in the samples from Hole 84IB in the Tonga forearc are similar to the organic acid assemblage detected in the Mariana forearc, that is, formate dominates the assemblage over acetate or propionate. These forearc organic acid assemblages may both have formed by a similar mechanism.
\end{abstract}

\section{INTRODUCTION}

Short-chain aliphatic acids are ubiquitous solutes in pore waters from Holocene through Paleozoic strata. In the marine environment, these materials have been documented in anoxic pore waters from Holocene nearshore sediments (Parkes and Taylor, 1983), in hydrothermally altered sediments from the actively rifting Guyamas Basin (Martens, 1990), and in pore waters associated with serpentine from the Mariana and Bonin forearc seamounts (Haggerty and Fisher, 1992). Although multiple origins for natural occurrences of aliphatic acids have been proposed (Lamar and Goerlitz, 1963; Carothers and Kharaka, 1978; Eglinton et al., 1987; Lundegard and Senftle, 1987; Barth et al., 1988; Haggerty and Fisher, 1992), their presence in pore waters indicates the existence of a complex organic precursor.

Here we describe the distribution and occurrence of short-chain aliphatic acids in a backarc basin setting. In addition, we present analyses from two drill sites in the Tonga forearc.

\section{METHODS}

Interstitial water was obtained on board the JOIDES Resolution by squeezing sediments in a Carver hydraulic press. As soon as cores arrived on deck, whole-round sections of core were removed by slicing the plastic core tube and capping both ends. No acetone was used to seal the plastic caps to the ends of the whole-round cores. The sediment samples were removed from the plastic core liner and scraped with a stainless-steel spatula to remove the outer layer (possibly contaminated) and then placed in a stainless-steel squeezer. Both the squeezer and the sediment samples were handled with plastic gloves to avoid potential contamination. The squeezer was placed in a Carver hydraulic press and squeezed at pressures of up to about $3,300 \mathrm{psi}$. The interstitial water was retrieved in a plastic syringe and was then filtered through a polysulfone filter for removal of fine particles. See the "Explanatory Notes" chapter of the Initial Reports

\footnotetext{
'Hawkins. J., Parson, L., Allan. J.. et al.. 1994. Proc. ODP. Sci. Results. 135: College Station, TX (Ocean Drilling Program).

${ }^{2}$ Department of Geosciences, University of Tulsa, 600 South College Avenue. Tulsa. OK 74104, U.S.A.

${ }^{3}$ AMOCO Production Company, P.O. Box 3385. Tulsa, OK 74102, U.S.A.
}

(Parson, Hawkins, Allan, et al., 1992, pp. 49-79) for a more detailed description of the extraction of interstitial waters.

An aliquot of the interstitial water was placed in a glass vial (break-seal ampule or serum bottle) and treated with a few milligrams of 1-hexadecylpyridinium chloride $\left(\mathrm{C}_{21} \mathrm{H}_{38} \mathrm{CIN}\right.$, CAS No. 6004-24-6, Kodak Product No. 05361). 1-hexadecylpyridinium chloride dissolved in the pore-water sample and inhibited bacterial degradation of organic compounds. This quaternary ammonium salt was chosen in preference to $\mathrm{HgCl}_{2}$ because of its lower toxicity to humans. Previous experiments at AMOCO Research Laboratory showed that this quaternary ammonium salt has the same preservative value for organic acids as $\mathrm{HgCl}_{2}$. The best preservation is achieved when using this salt or $\mathrm{HgCl}_{2}$ in glass containers.

Organic acids were determined using ion exclusion chromatography (ICE) (Dionex 2000i series chromatograph, S1 separator, membrane suppressor, $800-\mu \mathrm{M}$ octanesulfonic acid eluant, tetrabutylammonium hydroxide regenerant, conductivity detection), as described in Haggerty and Fisher (1992) in a study of Ocean Drilling Program (ODP) Leg 125 interstitial waters from the Mariana and Bonin forearcs. Before injection, sulfate was removed by reacting the sample with excess $\mathrm{BaCl}_{2}$ ( $12 \mathrm{mg} / \mathrm{mL}$ sample), and halides were removed by passing the sample through a silver-formed ion exchange resin (Dionex OnGuard-Ag cartridge). To remove contaminants and condition the packing, the pretreatment cartridge was successively flushed with $5 \mathrm{~mL}$ of distilled water followed by $3 \mathrm{~mL}$ of analyte.

Sample volumes (typically $5 \mathrm{~mL}$ ) were too small to conduct recovery efficiency experiments. Recovery efficiency was evaluated by applying the pretreatment methodology to organic acid standard mixtures, and comparing the analytical results for the treated standards to those of the same standard but without pretreatment. See Haggerty and Fisher (1992) for chromatograms and other analytical details (method accuracy and lack of artifact generation). In the present study, experimentally determined average recoveries were $95 \%$, and showed no preference for individual acid anions. These results compare directly with those obtained for the pore waters analyzed from Leg 125, even though organic acid concentrations in the present study are an order of magnitude lower.

With an eluant flow rate of $0.8 \mathrm{~mL} / \mathrm{min}$, all peaks had eluted in 17 min. Observed peaks were identified by retention time matching to verified pure compounds; some peaks remained unidentified. The analyses were targeted for the following organic acids: malonate, formate, acetate, propionate, and butyrate. 
Table 1. Organic acid analyses from Leg 135 interstitial waters.

\begin{tabular}{|c|c|c|c|c|c|c|c|c|c|}
\hline \multirow{2}{*}{$\begin{array}{l}\text { Core, section, } \\
\text { interval }(\mathrm{cm})\end{array}$} & \multirow{2}{*}{$\begin{array}{l}\text { Depth } \\
\text { (mbsf) }\end{array}$} & \multicolumn{2}{|c|}{ Formate } & \multicolumn{2}{|c|}{ Acetate } & \multicolumn{2}{|c|}{ Propionate } & \multicolumn{2}{|c|}{ Butyrate } \\
\hline & & $(\mathrm{mg} / \mathrm{L})$ & $(\mu \mathrm{M} / \mathrm{L})$ & $(\mathrm{mg} / \mathrm{L})$ & $(\mu \mathrm{M} / \mathrm{L})$ & $(\mathrm{mg} / \mathrm{L})$ & $(\mu \mathrm{M} / \mathrm{L})$ & $(\mathrm{mg} / \mathrm{L})$ & $(\mu \mathrm{M} / \mathrm{L})$ \\
\hline \multicolumn{10}{|l|}{$135-834 \mathrm{~A}-$} \\
\hline $1 \mathrm{H}-4,140-150$ & 5.90 & 1.4 & 31.1 & 3.1 & 52.5 & 2.7 & 36.9 & 0 & 0 \\
\hline $2 \mathrm{H}-4,140-150$ & 13.50 & 0.5 & 11.1 & 0 & 0 & 5.2 & 71.2 & 0 & 0 \\
\hline $3 \mathrm{H}-4,140-150$ & 23.00 & 0.4 & 8.9 & 0 & 0 & 0.9 & 12.3 & 0 & 0 \\
\hline $4 \mathrm{H}-4,140-150$ & 32.50 & 0 & 0 & 0 & 0 & 2.0 & 27.4 & 0 & 0 \\
\hline $5 \mathrm{H}-4,140-150$ & 42.00 & 0 & 0 & 0 & 0 & 0 & 0 & 0 & 0 \\
\hline $9 \mathrm{H}-4,140-150$ & 80.00 & 0 & 0 & 0 & 0 & 2.1 & 28.7 & 0 & 0 \\
\hline $12 X-1,140-150$ & 104.30 & 0 & 0 & 0 & 0 & 2.7 & 36.9 & 0 & 0 \\
\hline $16 \mathrm{X}-1,140-150$ & 133.30 & 0.3 & 6.7 & 0.4 & 6.8 & 4.3 & 58.8 & 0 & 0 \\
\hline \multicolumn{10}{|l|}{$135 \mathrm{~A}-835 \mathrm{~A}-$} \\
\hline $1 \mathrm{H}-4,140-150$ & 5.90 & 0.4 & 8.9 & 0 & 0 & 1.2 & 16.4 & 0 & 0 \\
\hline $2 \mathrm{H}-4,140-150$ & 15.40 & 0.1 & 2.2 & 0.4 & 6.8 & 0.5 & 6.8 & 0 & 0 \\
\hline $3 \mathrm{H}-4,140-2150$ & 24.90 & 0.2 & 4.4 & 0 & 0 & 1.2 & 16.4 & 0 & 0 \\
\hline $4 \mathrm{H}-4,140-150$ & 34.40 & 0.3 & 6.7 & 0 & 0 & 1.2 & 16.4 & 0 & 0 \\
\hline $6 \mathrm{H}-4,140-150$ & 53.40 & 0.5 & 11.1 & 0 & 0 & 0.7 & 9.6 & 0 & 0 \\
\hline $8 \mathrm{H}-4,140-150$ & 72.40 & 0.3 & 6.7 & 0 & 0 & 0.4 & 5.5 & 0 & 0 \\
\hline $10 \mathrm{H}-4,140-150$ & 91.40 & 0.4 & 8.9 & 0 & 0 & 0.6 & 8.2 & 0 & 0 \\
\hline $12 \mathrm{H}-4,140-150$ & 110.40 & 0.3 & 6.7 & 0 & 0 & 1.2 & 16.4 & 0 & 0 \\
\hline $14 \mathrm{H}-4,140-150$ & 129.40 & 0.4 & 8.9 & 0 & 0 & 0 & 0 & 0 & 0 \\
\hline $16 \mathrm{H}-6,140-150$ & 151.35 & 0.3 & 6.7 & 0 & 0 & 0 & 0 & 0 & 0 \\
\hline \multicolumn{10}{|l|}{$135-836 \mathrm{~A}$} \\
\hline $2 \mathrm{H}-4,140-150$ & 7.10 & 0.3 & 6.7 & 0 & 0 & 0.8 & 10.9 & 0 & 0 \\
\hline $3 \mathrm{H}-5,140-150$ & 17.98 & 0.6 & 13.3 & 0 & 0 & 1.1 & 15.1 & 0 & 0 \\
\hline \multicolumn{10}{|l|}{$135-837 \mathrm{~A}$} \\
\hline $1 \mathrm{H}-3,140-150$ & 4.40 & 0.3 & 6.7 & 0 & 0 & 1.0 & 13.7 & 0 & 0 \\
\hline $4 \mathrm{H}-4,140-150$ & 32.90 & 0.4 & 8.9 & 0 & 0 & 1.1 & 15.1 & 0 & 0 \\
\hline $6 \mathrm{H}-5,140-150$ & 53.40 & 0.4 & 8.9 & 0 & 0 & 1.2 & 16.4 & 0 & 0 \\
\hline $8 \mathrm{H}-4,140-150$ & 70.90 & 0.2 & 4.4 & 0 & 0 & 1.0 & 13.7 & 0 & 0 \\
\hline \multicolumn{10}{|l|}{$135-838 \mathrm{~A}-$} \\
\hline $2 \mathrm{H}-4,140-150$ & 9.60 & 0.4 & 8.9 & 0 & 0 & 1.7 & 23.3 & 0 & 0 \\
\hline $4 \mathrm{H}-4,140-150$ & 28.60 & 0.4 & 8.9 & 0 & 0 & 2.0 & 27.4 & 0 & 0 \\
\hline $8 \mathrm{H}-4,140-150$ & 66.60 & 0.4 & 8.9 & 0 & 0 & 1.2 & 16.4 & 0 & 0 \\
\hline \multicolumn{10}{|l|}{ 135-839A- } \\
\hline $1 \mathrm{H}-2,140-150$ & 2.90 & 0.3 & 6.7 & 0 & 0 & 3.0 & 41.1 & 0 & 0 \\
\hline $2 \mathrm{H}-4,140-150$ & 10.40 & 0.5 & 11.1 & 0 & 0 & 1.1 & 15.1 & 0 & 0 \\
\hline $3 \mathrm{H}-4,140-150$ & 19.90 & 0 & 0 & 0 & 0 & 0 & 0 & 0 & 0 \\
\hline $4 \mathrm{H}-5,140-150$ & 30.90 & 0.2 & 4.4 & 0 & 0 & 2.5 & 34.2 & 0 & 0 \\
\hline $6 \mathrm{H}-4,140-150$ & 48.40 & 0.5 & 11.1 & 0 & 0 & 1.3 & 17.8 & 0 & 0 \\
\hline $8 \mathrm{H}-4,140-150$ & 67.40 & 0.5 & 11.1 & 0.2 & 3.4 & 1.5 & 20.5 & 0 & 0 \\
\hline $10 \mathrm{H}-5,140-150$ & 87.90 & 0.2 & 4.4 & 0 & 0 & 0.5 & 6.8 & 0 & 0 \\
\hline \multicolumn{10}{|l|}{$135-840 \mathrm{~B}-$} \\
\hline $12 \times-4,140-150$ & 109.88 & 0.5 & 11.1 & 0.2 & 3.4 & 1.5 & 20.5 & 0 & 0 \\
\hline $13 \times-2,140-150$ & 118.00 & 0.3 & 6.7 & 0 & 0 & 1.0 & 13.7 & 0 & 0 \\
\hline 135-840C- & & & & & & & & & \\
\hline $3 \mathrm{H}-2,126-136$ & 59.76 & 0.6 & 13.3 & 0 & 0 & 1.4 & 19.2 & 0.3 & 3.4 \\
\hline $4 \mathrm{H}-4,140-150$ & 72.40 & 0.2 & 4.4 & 0 & 0 & 0 & 0 & 0 & 0 \\
\hline $5 \mathrm{H}-1,139-147$ & 125.39 & 0.6 & 13.3 & 0 & 0 & 1.8 & 24.6 & 0 & 0 \\
\hline 135-841A- & & & & & & & & & \\
\hline $1 \mathrm{H}-4,140-150$ & 5.90 & 0 & 0 & 0 & 0 & 0 & 0 & 0 & 0 \\
\hline $2 \mathrm{H}-4,140-150$ & 14.40 & 0.2 & 4.4 & 0 & 0 & 1.0 & 13.7 & 0 & 0 \\
\hline $3 \mathrm{H}-4,140-150$ & 23.90 & 0.3 & 6.7 & 0 & 0 & 1.4 & 19.2 & 0 & 0 \\
\hline $4 \mathrm{H}-4,140-150$ & 33.40 & 0.3 & 6.7 & 0 & 0 & 1.1 & 15.1 & 0 & 0 \\
\hline $6 \mathrm{H}-4,140-150$ & 52.40 & 0.3 & 6.7 & 0 & 0 & 1.0 & 13.7 & 0 & 0 \\
\hline $8 \mathrm{H}-3,140-150$ & 69.90 & 0.3 & 6.7 & 0 & 0 & 0.4 & 5.5 & 0 & 0 \\
\hline $135-841 B-$ & & & & & & & & & \\
\hline $2 \mathrm{R}-1,142-150$ & 171.22 & 0.5 & 11.1 & 0.2 & 3.4 & 0.9 & 12.3 & 0 & 0 \\
\hline $8 \mathrm{R}-1,75-85$ & 228.45 & 0.7 & 15.5 & 0.6 & 10.2 & 0.5 & 6.8 & 0 & 0 \\
\hline 11R-1, 61-74 & 257.31 & 0.4 & 8.9 & 0.3 & 5.1 & 1.1 & 15.1 & 0 & 0 \\
\hline $15 \mathrm{R}-1,135-150$ & 296.25 & 0.5 & 11.1 & 0.4 & 6.8 & 0.3 & 4.1 & 0 & 0 \\
\hline $21 \mathrm{R}-1,12-32$ & 352.22 & 1.3 & 28.9 & 0.3 & 5.1 & 0.6 & 8.2 & 0 & 0 \\
\hline $51 R-2,0-19$ & 642.80 & 0.4 & 8.9 & 0.3 & 5.1 & 0.5 & 6.8 & 0 & 0 \\
\hline
\end{tabular}

\section{RESULTS}

Observed concentrations of determined organic acids are given in Table 1. Organic acids can be found in the sediments at all Leg 135 sites. Propionate and formate are persistently present (only 5 of the 49 samples did not contain both formate and propionate). Acetate is rare, occurring in only 10 of the 49 pore-water samples. Aside from Sample 135-834A-1H-4, 140-150 cm, acetate never exceeds a concentration of $10 \mu \mathrm{M} / \mathrm{L}$. Although acetate was found at four of the seven sites (Sites $834,839,840$, and 841 ), it was only present in the deeper (below 171.22 mbsf) samples at Site 841, where it occurred in all of the rotary cores sampled for interstitial water. Butyrate was detected in only one sample (Sample 135-840C-4H-4, 140-150 cm); no malonate was observed in any of the interstitial water samples.

A cross plot of the concentrations of propionate and formate is given in Figure 1. Propionate is nearly always more abundant than formate. Propionate ranges in concentration from 0 to $71.2 \mu \mathrm{M} / \mathrm{L}$ with a median concentration of $15.1 \mu \mathrm{M} / \mathrm{L}$. In contrast, formate ranges in 


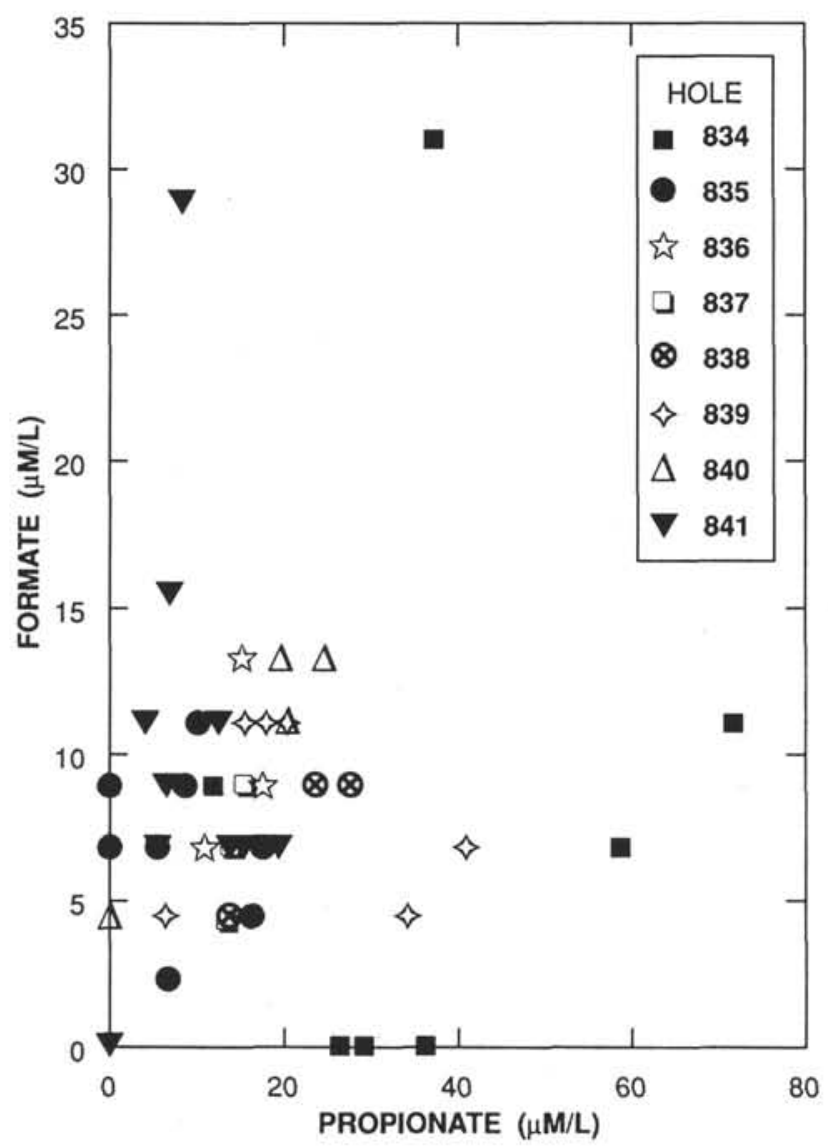

Figure 1. Comparison of the concentrations of formate and propionate. See Table 1 for data.

concentration from 0 to $31.1 \mu \mathrm{M} / \mathrm{L}$ with a median concentration of $7.8 \mu \mathrm{M} / \mathrm{L}$. As shown in Figure 1, no readily discernable relationship is present between the concentrations of formate and propionate.

Figure 2 displays the profiles of organic acid concentrations vs. depth for backarc drill sites. Propionate typically dominates formate. At Site 834, both propionate and formate values markedly decrease to $42 \mathrm{mbsf}$. Below this depth, propionate values show a pronounced increase. At Site 835, no obvious depth relationship was observed for formate and propionate concentrations; acetate was detected in only one sample. At Site 839, propionate dominated the organic acid assemblage: propionate concentrations decreased with depth, formate concentrations remained relatively constant; and acetate was only detectable in one sample (Sample 135-839A-8H-4, 140-150 cm) at 67.4 mbsf.

Figure 3 illustrates the organic acid profiles for Sites 840 and 841 in the Tonga forearc. Above $59.8 \mathrm{mbsf}$ in Holes $840 \mathrm{~B}$ and $840 \mathrm{C}$, no interstitial water samples were available for organic acid analysis. Data from Site 840 show that propionate typically dominated the organic acid assemblage. The data from Site 841 show that propionate concentrations typically dominated the assemblage above $228 \mathrm{mbsf}$; below this depth formate dominates over propionate. The Site 841 data differ from all other sites in that acetate was found in all samples from 171.22 to $642.8 \mathrm{mbsf}$. The overall trend is a decrease in propionate concentration and an increase in acetate and formate concentrations with increasing sub-bottom depth.

\section{DISCUSSION}

\section{Comparison to Previous Work}

The abundance and representation of aliphatic acid anions found in these interstitial waters is substantially different from that described for the Mariana and Bonin forearcs using the same analytical method (Haggerty and Fisher, 1992). First, aliphatic acid anions are generally not present in interstitial waters collected from the Mariana and Bonin forearcs; organic acid anions are almost exclusively restricted to pore waters squeezed from serpentines. In the present study, aliphatic acid anions were found in both pelagic sediments and sediments containing altered igneous components. Second, formate and acetate are the abundant aliphatic acid anions in the Mariana forearc serpentine seamount samples, and they typically show formate at a higher concentration than acetate. In contrast, interstitial waters from the Tonga arc-trench system show formate and propionate to be the dominant aliphatic acid anions, with rare acetate occurrences. In addition, in this study, propionate was nearly always present at a higher concentration than formate. Third, the overall abundance of aliphatic acid anions found in this study is approximately an order of magnitude less than that found in the Mariana and Bonin forearc study.

\section{Individual Profiles}

Backarc Sites 834 and 835 are thought to represent lateral flow of pore water in a large-scale, convective, circulation cell near the base of the sedimentary section (see Lavoie et al., this volume; Parson, Hawkins, Allan, et al., 1992, "Site 834" and "Site 835" chapters). The organic acid profiles from Site 835 (Fig. 2) provides no unambiguous support for a convective cell. However, the profile for Site 834 (Fig. 2 ) is suggestive of hydrothermal activity at depth. Despite a decrease in sedimentary organic carbon from 0.27 to less than $0.1 \%$ (Parson, Hawkins, Allan, et al., 1992, "Site 834" chapter), the propionate values show a steady increase in the lower portion of the sedimentary section. The increase in organic acid concentrations may be related to a convective cell.

The profile from backarc Site 839 (Fig. 2) appears to reflect simple microbial production of aliphatic acid anions in near-surface sediments. The decrease in concentration with increasing depth may represent diffusive loss and microbial destruction. These concentrations do not appear to reflect downwelling at Site 839, as has been suggested by the physical properties data (see Lavoie et al., this volume). One would have expected no change in concentrations of organic acids with increasing sub-bottom depth, and uniformly low levels of aliphatic acid anion concentrations in a downwelling situation.

The two Tonga forearc sites, Sites 840 and 841 , show similar organic acid patterns (Fig. 3 ) in the sedimentary sections of the drill holes. In fact, they have comparable formate and propionate concentrations with propionate dominating over formate.

Below 228 mbsf at Site 841 (Fig. 3), the organic acid pattern is different from all the other profiles from Leg 135. This suggests a different origin for the organic acids. Because the pattern is the same as that observed in the Mariana forearc and because serpentine has been dredged from nearby areas in the Tonga forearc (Vallier et al., 1985), the organic acids may have been formed by similar mechanisms.

\section{Sources for the Aliphatic Acid Anions}

The aliphatic acid anions present in the sampled interstitial waters must be derived from complex organic precursors. The most likely precursor material for the aliphatic acid anions would be sedimentary organic matter. The aliphatic acid anions could be generated biochemically (microbial alteration of sedimentary organic matter), chemically (alkaline hydrolysis of sedimentary organic matter in basic microenvironments associated with the hydrolysis of igneous components), or thermally (thermal maturation of sedimentary organic matter).

The extremely low levels of organic carbon found in the sediment at all Leg 135 sites argues against a sedimentary organic matter source for the aliphatic acid anions found in interstitial waters. Of the 156 sediments analyzed for total organic carbon (material representing all eight Leg 135 drill sites), only one sample exceeded $0.4 \%$ total organic carbon (TOC), and the average sediment contained only 

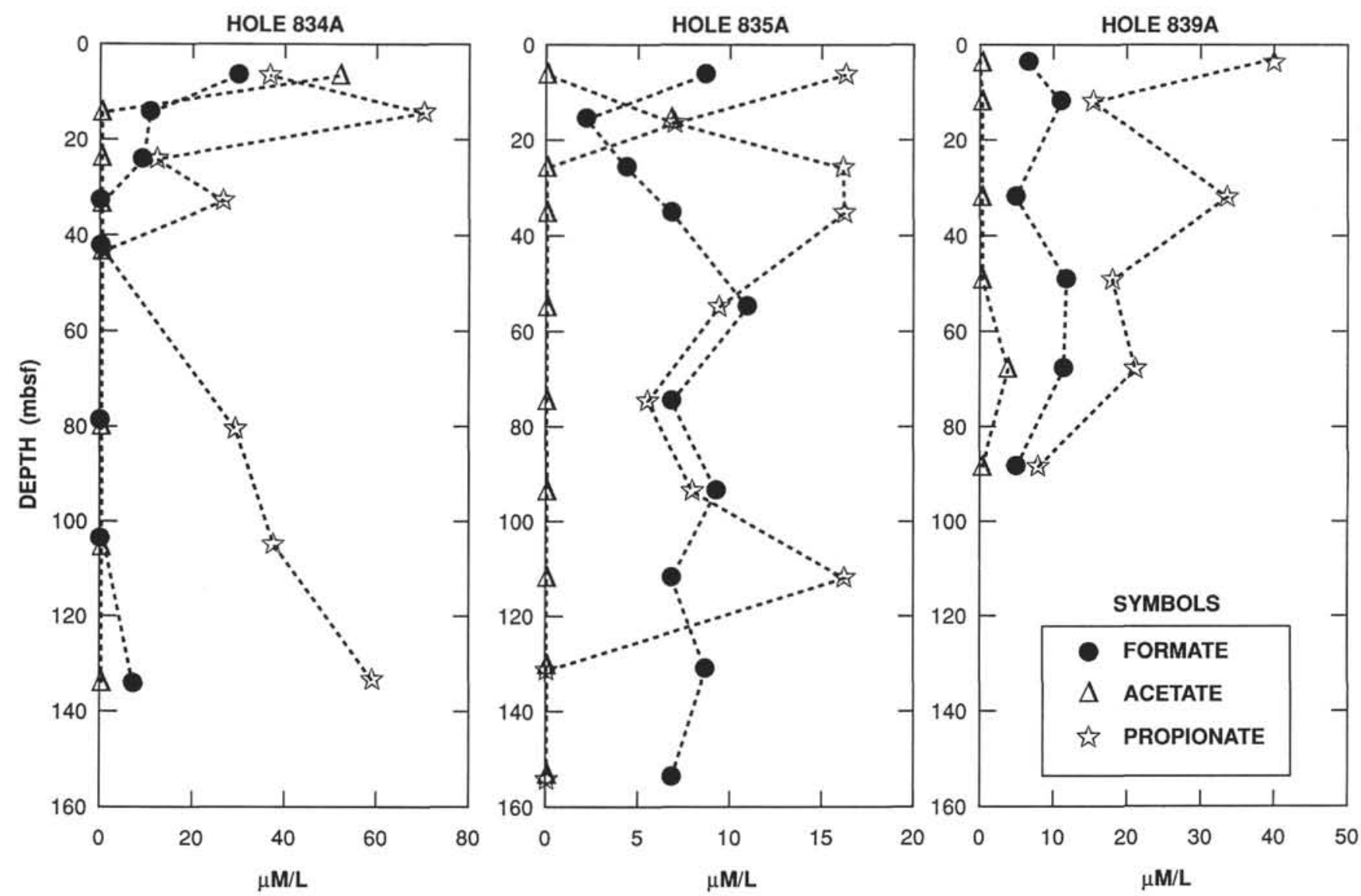

Figure 2. Comparison of formate, acetate, and propionate values from backarc Holes 834A, 835A, and 839A vs. depth. See Table 1 for data. Concentrations of organic acids in $\mu \mathrm{M} / \mathrm{L}$ and depth in meters below seafloor (mbsf).

$0.05 \%$ TOC (Fowler, this volume). This carbon was mostly reworked and oxidized material, which provides a poor bacterial substratum.

Even so, evidence does exist for microbial activity at Site 841 . Ammonium is present in all analyzed interstitial water samples from Leg 135 (see Parson, Hawkins, Allan, et al., 1992, site chapters for Sites 835-841). Ammonia was analyzed on board the ship from a split of the same interstitial water sample used in this study, but it was analyzed before the addition of the pickling agent, 1-hexadecylpyridinium chloride $\left(\mathrm{C}_{21} \mathrm{H}_{38} \mathrm{CIN}\right)$.

Ammonium in these interstitial waters must have an in-situ source because the overlying waters would readily oxidize it. One possible source of the ammonium is equilibrium desorption of ammonium as an exchangeable cation from clays that were transported by gravity flow to Site 841 . We have no evidence to discount ammonium desorption from clays, but the existing mineralogic data presented in the site chapters of Parson, Hawkins, Allan, et al. (1992) is inadequate for a detailed mass balance calculation (i.e., no clay mineralogy data). Moreover, if the ammonium were sourced from clay desorption, then there would be no relationship between ammonium abundance and organic acid concentration and representation.

Deamination of amino acids derived from algal and other proteins will produce organic acids (Kuznetsov, 1970), and this is the most plausible source of the interstitial water ammonia. The general presence of ammonia in the interstitial waters, therefore, implies the presence of at least some liable organic compounds in these sediments. As additional support for a sedimentary source for the ammonia observed in these interstitial waters, the ammonium concentration profile observed for Site 841 (Fig. 4) is indicative of a localized sedimentary source with diffusive transport toward both the overlying water and the underlying material (see, e.g., Hesse, 1986, fig. 17, which shows the pore-water signature from the dissolution of evaporite minerals at depth).

Both oxidative and reductive deamination yield organic acids in addition to ammonia; therefore, the origin of at least some of the aliphatic acid anions present in these pore waters may lie in the decomposition of minor amounts of sedimentary proteins. The source of these proteins is probably organic matter caught in gravity flow deposits. Oxidizing environments such as the one that exists at the sediment/water interface do not preserve complex proteins (Nissenbaum et al., 1972).

The general pattern of propionate being more abundant than formate is consistent, with reductive deamination being the main source of ammonium. Oxidative deamination yields shorter chain organic acids than reductive deamination (see Kuznetsov, 1970, p. 268). The source of the labile organic matter is probably the gravity flow deposits, as suggested by Rothwell (this volume) and Thompson et al. (this volume). Abundant evidence exists for the presence of numerous gravity flow deposits in these sediments (see Parson, Hawkins, Allan, et al., site chapters for Sites 834-841). These gravity flow deposits represent a means for directly importing sediments enriched in labile surficial organic carbon (see Thompson et al., this volume).

Another possible source for the aliphatic acid anions is alkaline hydrolysis of ester linkages as a result of the production of highly alkaline microenvironments during the hydration of igneous material. Vitreous material is common in these sediments, and persistent acetate as well as formate and propionate are associated with the deeper samples from Site 841 .

Below $228 \mathrm{mbsf}$ at Site $84 \mathrm{I}$, formate typically dominates the organic acids; this is similar to the organic acid assemblage recorded 

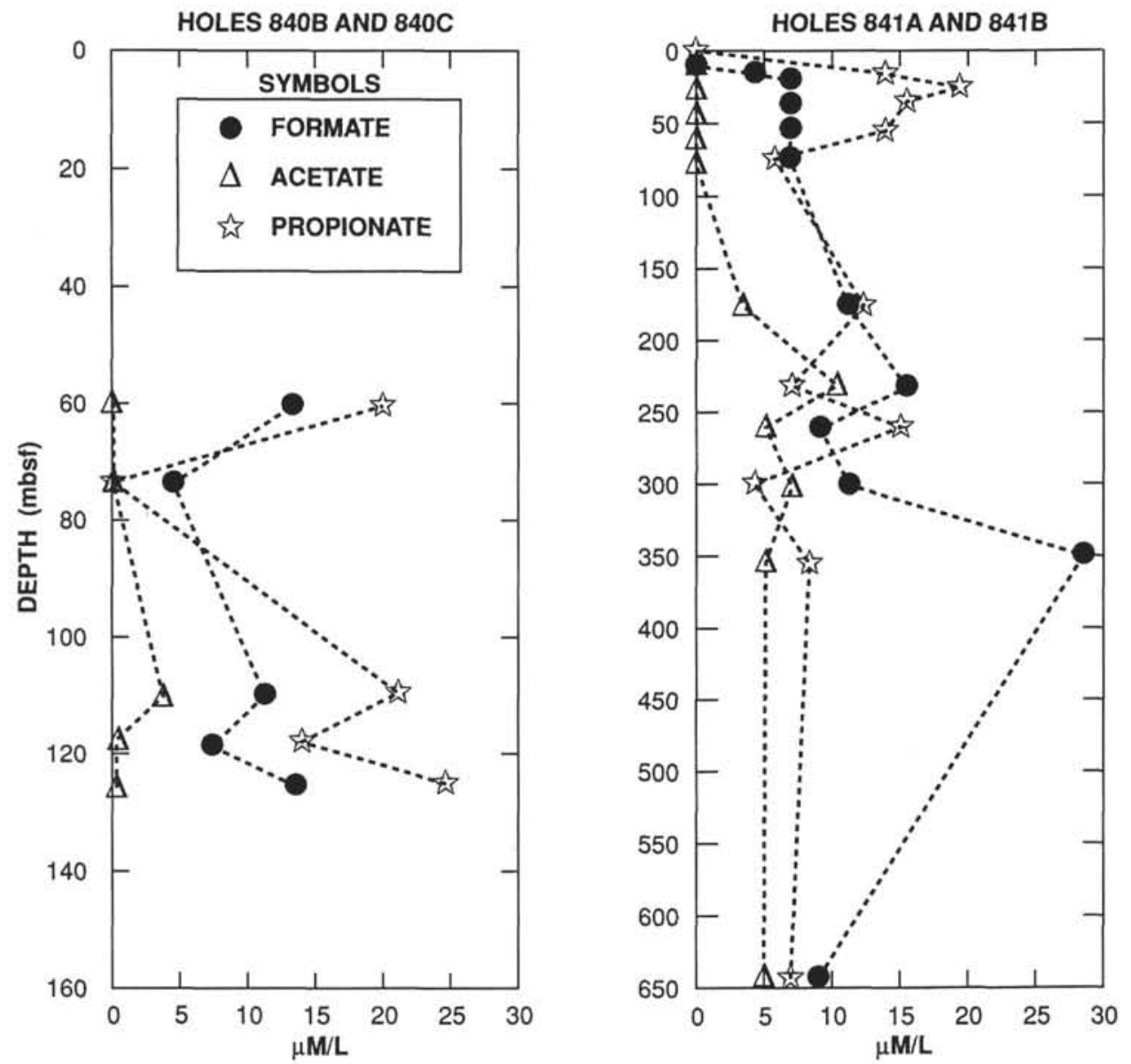

Figure 3. Comparison of formate, acetate, and propionate values from forearc Holes $840 \mathrm{~B}, 840 \mathrm{C}, 841 \mathrm{~A}$, and $841 \mathrm{~B}$ vs. depth. See Table 1 for data. Concentrations of organic acids in $\mu \mathrm{M} / \mathrm{L}$ and depth in meters below seafloor (mbsf).

from the Mariana interstitial waters that were squeezed from serpentine. This interesting assemblage of organic acids in the lower portion of the section at Site 841 may be associated with serpentine in the nearby area or they may be related to fluids bleeding from a major fault that cuts through this location in Core 135-841B-47R. In the Mariana forearc, this organic acid assemblage is suggested to be generated by alkaline hydrolysis of ester linkages or thermal maturation of organic matter at depth. Highly alkaline microenvironments are produced during serpentinization and could facilitate alkaline hydrolysis of ester linkages. Thermal maturation of organic matter from the downgoing slab could also produce organic acids that may subsequently become entrained in fluids rising through the overlying plate, possibly along faults, and these fluids could aid in the development of the Mariana serpentine seamounts. In the Tonga forearc, serpentinite has been dredged from nearby locations (Vallier et al., 1985); it is conceivable, therefore, that serpentine may have been in the proximity of the drill site. An alternate interpretation is that these acids may also have formed at a greater depth and were transported along the fault observed in Core 135-841B-47R. It should be noted that the concentrations of the organic acids in the Tonga forearc are an order of magnitude lower than those found in the Mariana forearc serpentine seamounts.

A thermal origin for the organic acid anions found in the base of Site 834 is possible. Although it has been suggested that seawater is downwelling at Site 839 and convecting at Site 835 through backarc materials, the evidence for this is not strong, as these proposed downwelling and upwelling areas do not display organic acid anion profiles indicating either dilution by downwelling seawater or enrichment from a deep thermal aliphatic acid anion source. Only the aliphatic acid profiles from Site 834 display potential enrichment from a deep thermal organic acid source.

\section{CONCLUSIONS}

The pattern of organic acid anions found in interstitial waters from the Tonga arc-trench system differs from that described from the Mariana and Bonin forearc. In the Tonga arc-trench system, organic acids are present in both sediments and lithified materials, they are in much lower abundance (approximately 10 times) when present, and they display a pattern in which longer chain acid anions (propionate) dominate over formate, but with acetate rarely present. In contrast, the Mariana-Bonin study showed organic acid anions to be generally absent from interstitial waters squeezed from sediments but present in the interstitial waters associated with serpentines and to have formate present in typically greater abundance than acetate or propionate with propionate rarely present.

Despite the fact that the organic matter present in all Leg 135 sediments is described as being in extremely low abundance and to be largely reworked and oxidized sedimentary organic matter, it is the most likely source for the majority of the organic acids found in most Leg 135 interstitial waters. Although it is possible that the organic acid anions may have been produced by alkaline hydrolysis of ester linkages in highly alkaline microenvironments associated with the hydrolysis of igneous materials, a microbial production of the organic 


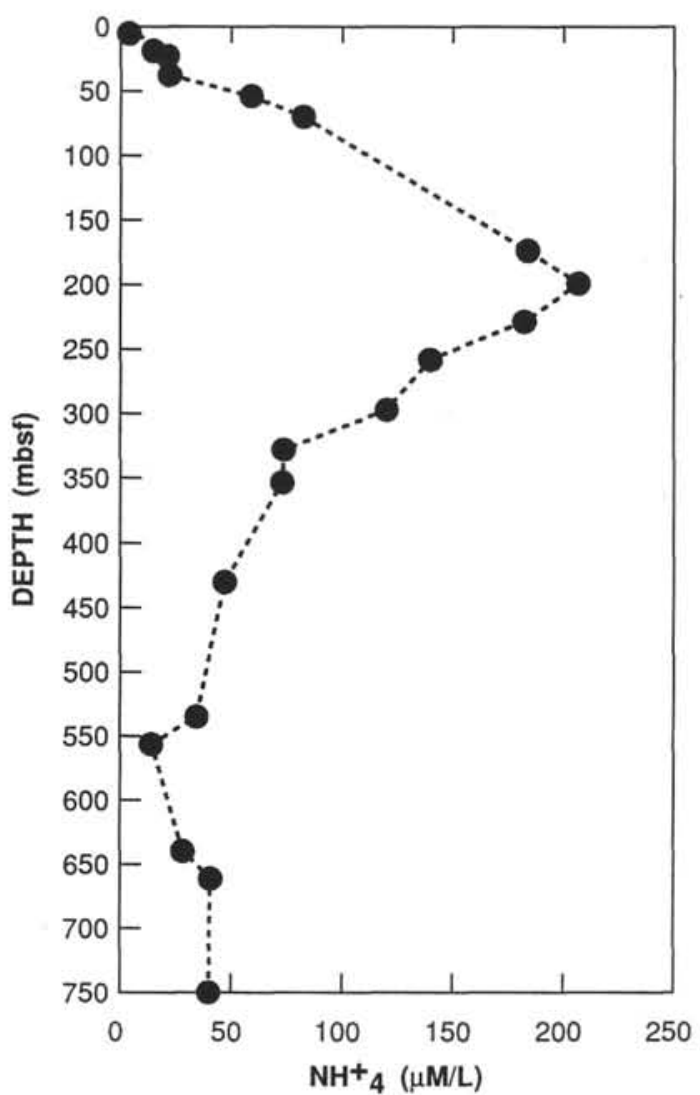

Figure 4. Ammonium concentrations in $\mathrm{mM} / \mathrm{L}$ vs. depth in meters below seafloor (mbsf) at Site 841. Data from shipboard analyses (Parson, Hawkins. Allan, et al., 1992, p. 628).

acids in the majority of the Leg 135 sites is more likely. Ammonia is generally present in the Leg 135 interstitial waters. The source of this ammonia is almost certainly from the deamination of amino acids derived from sedimentary proteinaceous material. Because reductive deamination would preferentially yield higher carbon number acids compared with oxidative deamination, we suggest that reductive deamination of amino acids is one of main sources of both the ammonia and organic acids in these interstitial waters.

The association of higher concentrations of organic acids as well as the persistent presence of acetate in the deeper portion of Site 841, and the presence of nearby serpentine, suggest that alkaline hydrolysis of ester linkages may be an important source of organic acid anions, or the acids may have formed at a greater depth and were transported along a fault. A thermal origin may be responsible for the production of the organic acids associated with Site 834 in a convective cell setting.

\section{ACKNOWLEDGMENTS}

The authors thank the Leg 135 Scientific Party and the shipboard personnel of the JOIDES Resolution for collecting the samples. J.A. Haggerty thanks the JOI-USSAC committee for support of the postcruise science. The authors also thank AMOCO Production Company for access to its analytical water laboratory, and Carl Bennett for his aid during the initial setup of the instrumentation.

\section{REFERENCES}

Barth. T., Borgund, A.E., Hopland, A.L., and Graue, A., 1988. Volatile organic acids produced during kerogen maturation: amounts, composition and role in migration of oil. Organic Geochem., 13:461-465.

Carothers, W.W., and Kharaka, Y.K., 1978. Aliphatic acids in oil field watersimplications for origin of natural gas. AAPG Bull., 62:244I-2453.

Eglinton, T.I., Curtis, C.D., and Rowland, S.J., 1987. Generation of watersoluble organic acids from kerogen during hydrous pyrolysis: implications for porosity development. Mineral. Mag., 51:495-503.

Haggerty, J.A., and Fisher, J.B., 1992. Short-chain organic acids in interstitial waters from Mariana and Bonin forearc serpentines: Leg 125. In Fryer, P., Pearce, J.A., Stokking, L.B., et al., Proc. ODP, Sci. Results, 125: College Station, TX (Ocean Drilling Program), 387-395.

Hesse, R., 1986. Diagenesis \#11. Early diagenetic pore water/sediment interaction: modern offshore basins. Geosci. Can., 13:165-196.

Kuznetsov, S.I., 1970. The Microflora of Lakes and Its Geochemical Activity: Austin, TX (Univ. of Texas Press).

Lamar, W.L., and Goerlitz. D.F., 1963. Characterization of carboxylic acids in unpolluted streams by gas chromatography. J. Am. Water Works Assoc., 55:797-802.

Lundegard, P.D., and Senftle, J.T., 1987. Hydrous pyrolysis: a tool for the study of organic acid synthesis. Appl. Geochem., 2:605-612.

Martens, C.S., 1990. Generation of short chain organic acid anions in hydrothermally altered sediments of the Guaymas Basin, Gulf of California. Appl. Geochem., 6:71-76.

Nissenbaum, A., Baedecker, M.J., and Kaplan, I.R., 1972. Organic geochemistry of Dead Sea sediments. Geochim. Cosmochim. Acta, 36:709-727.

Parkes, R.J., and Taylor. J., 1983. Analysis of volatile fatty acids by ion-exclusion chromatography, with special reference to marine pore water. Mar. Biol., 77:113-118.

Parson, L., Hawkins, J., Allan, J., et al., 1992. Proc. ODP, Init. Repts., 135: College Station, TX (Ocean Drilling Program).

Vallier, T.L., O'Connor, R.M., Scholl, D.W., Stevenson, A.J., and Quinterno, P.J., 1985. Petrology of rocks dredged from the landward slope of the Tonga Trench: implications for middle Miocene volcanism and subsidence of the Tonga Ridge. In Scholl, D., and Vallier, T.L. (Eds.), Geology and Offshore Resources of Pacific Island Arcs-Tonga Region. Circum-Pac. Counc. Energy Miner. Resour., Earth Sci. Ser., 2:109-120.

Abbreviations for names of organizations and publication titles in ODP reference lists follow the style given in Chemical Abstracts Service Source Index (published by American Chemical Society).

Date of initial receipt: 1 June 1992

Date of acceptance: 23 March 1993

Ms 135SR-126 